\title{
Assessment of impact of climate change on water resources: a long term analysis of the Great Lakes of North America
}

\author{
E. McBean ${ }^{1}$ and H. Motiee ${ }^{2}$ \\ ${ }^{1}$ School of Engineering, University of Guelph, Guelph, N1G 2W1, Canada \\ ${ }^{2}$ Water Eng. Faculty, Power and Water University of Technology (PWUT), Tehran, Iran \\ Received: 28 August 2006 - Published in Hydrol. Earth Syst. Sci. Discuss.: 11 October 2006 \\ Revised: 18 December 2007 - Accepted: 4 January 2008 - Published: 11 February 2008
}

\begin{abstract}
In the threshold of the appearance of global warming from theory to reality, extensive research has focused on predicting the impact of potential climate change on water resources using results from Global Circulation Models (GCMs). This research carries this further by statistical analyses of long term meteorological and hydrological data. Seventy years of historical trends in precipitation, temperature, and streamflows in the Great Lakes of North America are developed using long term regression analyses and Mann-Kendall statistics. The results generated by the two statistical procedures are in agreement and demonstrate that many of these variables are experiencing statistically significant increases over a seven-decade period. The trend lines of streamflows in the three rivers of St. Clair, Niagara and St. Lawrence, and precipitation levels over four of the five Great Lakes, show statistically significant increases in flows and precipitation. Further, precipitation rates as predicted using fitted regression lines are compared with scenarios from GCMs and demonstrate similar forecast predictions for Lake Superior. Trend projections from historical data are higher than GCM predictions for Lakes Michigan/Huron. Significant variability in predictions, as developed from alternative GCMs, is noted.
\end{abstract}

Given the general agreement as derived from very different procedures, predictions extrapolated from historical trends and from GCMs, there is evidence that hydrologic changes particularly for the precipitation in the Great Lakes Basin may be demonstrating influences arising from global warming and climate change.

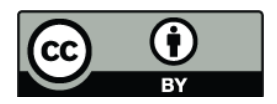

Correspondence to: $\mathrm{E}$. McBean

(emcbean@uoguelph.ca)

\section{Introduction}

The Great Lakes of North America, namely Lake Superior, Huron, Michigan, Erie and Ontario, represent one of the most important water resources in the world, and provide water for multipurpose for more than fifty million people in eastern North America. Combined, the Great Lakes and their connecting channels comprise the largest fresh surface water system on earth (Fig. 1a), holding approximately 20 percent of the world's fresh surface water supply (De Loë, 2000; GLIN, 2005).

As an indication of the enormous size of the lakes, the estimated cumulative volume of the five lakes is $6 \times 10^{15}$ (six quadrillion) gallons which is sufficient water to flood North America to an average depth of $1 \mathrm{~m}$. Of the Lakes, the most upstream, largest, and deepest is Lake Superior (Hunter, 1993).

The diversity of uses and the magnitude of the Great Lakes system interactions are testimony to the enormous importance of this freshwater system. However, the Great Lakes basin represents a drainage area of $770000 \mathrm{~km}^{2}$ in the United States and Canada (Croley, 1990). Since the water surface area is $244000 \mathrm{~km}^{2}$ (US EPA, 2005); it follows that the Great Lakes drain land areas only twice that of their surface area. It should be noted that there are no major storage reservoirs impounding water beyond the Lakes themselves and the detention times of the lakes (as per Table 1) are enormous. According to Allan and Hinz (2004), "components of stream flow may have changed over the course of the 20th Century due to natural events, including a wetter or drier climate, and to human influences, including dams and changing land use".

As a consequence of the above, the lengthy record of historical data allows assessment whether there are stresses acting on the Lakes, indicating long term change. Specifically, global climate changes may be occurring, resulting in

Published by Copernicus Publications on behalf of the European Geosciences Union. 


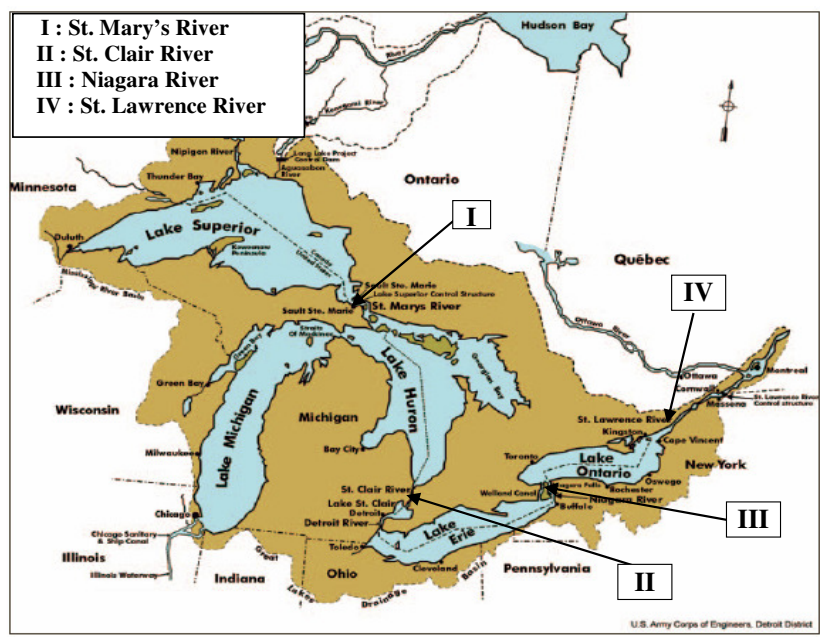

Fig. 1a. The Great Lakes Basin in North America.

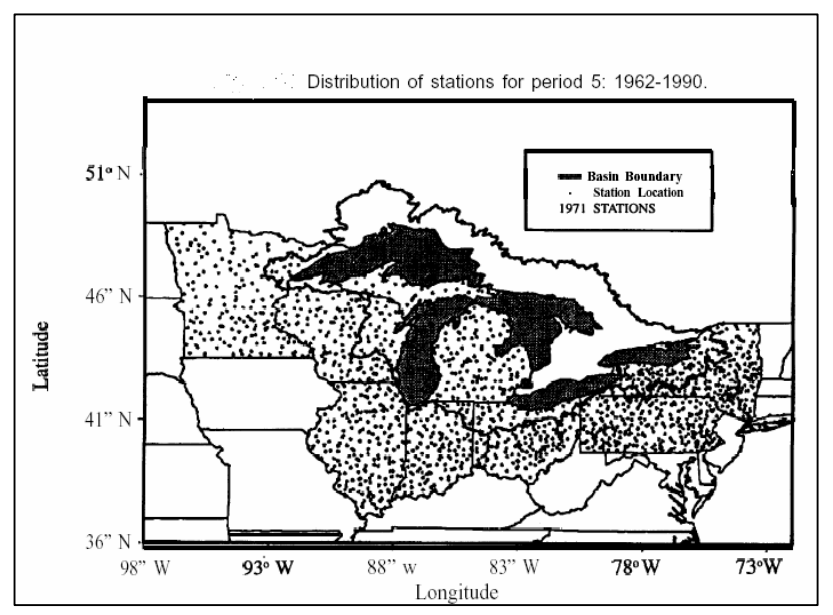

Fig. 1b. Distribution of stations in the Great Lakes basin between 1962-1990.

changes in precipitation, temperature, and flows, in terms of the water budget for the Great Lakes.

As a result of the size of the Lakes, there is continuing potential for water diversions to be constructed to divert flow from the Great Lakes, to export water to dry areas of North America such as the mid-western states of the USA (e.g. Dulmer et al., 2003).

As a result of the above, while there are enormous volumes of water in the Great Lakes, the relatively modest contributing drainage areas translate to enormous detention times for the Great Lakes, as summarized in Table 1. Hence, while the dimensions of the Great Lakes imply at first "glance" that they might support diversion of large quantities of water out of the watershed, any changes arising from climate change or water diversions may create long-term repercussions on water levels and water budgets. The result is an enormous need to understand the extent to which climate change is oc-
Table 1. Retention times for the Great Lakes.

\begin{tabular}{lccc}
\hline Individual Lake & \multicolumn{2}{c}{ Rank in World } \\
& by area & by volume & Retention Time (years) ${ }^{\mathrm{b}}$ \\
\hline Superior & 2 & 4 & 191 \\
Michigan & 4 & 6 & 99 \\
Huron & 5 & 7 & 22 \\
Erie & 11 & - & 2.6 \\
Ontario & - & 12 & 6 \\
\hline
\end{tabular}

Sources: ${ }^{\mathrm{a}}$ Beeton (2002) and ${ }^{\mathrm{b}}$ USEPA (2005).

curring. To address this issue, investigation procedures described herein include assessment of possible climate change impacts on the Great Lakes by:

(i) a review of historical trends of precipitation, temperatures and flows, and extrapolation of these historical trends to assess potential future scenarios; and,

(ii) estimation of the hydrologic impacts of climate change using global climate models (GCMs).

This paper utilizes both (i) and (ii) items, to provide insights into projected future possibilities for the Great Lakes.

\section{Global climate change and climate change models}

Trace constituents within the atmosphere, particularly water vapour, carbon dioxide, methane and ozone, function much like a "thermal blanket" around the earth. These constituents, commonly referred to as greenhouse gases, collectively total less than one percent of the atmosphere, but are extremely important in retarding the release of heat energy from the earth back into space. This natural "greenhouse effect" keeps the earth's average surface temperatures approximately $30^{\circ} \mathrm{C}$ warmer than simple radiation physics would suggest for a transparent atmosphere.

IPCC (1996 and 2002) reported that the current scientific estimate of the chemical composition of the atmosphere clearly indicates that concentrations of principal greenhouse gases are increasing rapidly, and appear already to exceed significantly, peak concentrations of the past 160000 years. Hengeveld (2000) stated that although the paleoclimatological and historical record trends are helpful to understand the cause and effect relationships within the climate system, climatologists still turn to computer simulations or Global Climate Models (GCMs) to assess the global scale response of the system to changes in radiative forcing functions. These models are based on fundamental principles of physics and are being tested against climate observations, to assess their ability to simulate adequately, the global climate change system. A number of these models have been developed and used for predicting climate changes. 
The most frequently employed GCMs include the Goddard Institute for Space Studies (GISS) after Hansen et al. (1983), Geophysical Fluid Dynamics Laboratory (GFDL) after Manabe and Weatherald (1980) and Canadian Climate Centre (CCC) after Boer et al. (1992, 2000). Gleick (1986, 1987) has indicated that the regional hydrologic impacts arising from the GCMs are not reliable at a regional scale for hydrologic variables and suggests that it is necessary to couple the climate models' scenarios with an hydrologic model to approximate the impact of climate change on regional water resources.

As an example, one of the future climate model scenarios that have been developed is a doubling of atmospheric carbon dioxide which has been predicted to occur in the mid 21 st century. The concern is that the increasing carbon dioxide concentrations in the atmosphere in the last thirty years (which have been documented), will result in increased warming of the earth's surface. This paper is not focused on the GCMs but instead focuses on measurements and statistical trend characterizations over time, for the precipitation, temperatures, and flows. For more details about the GCMs, interested readers are referred to the reference materials identified herein.

\section{Assessment of historical trends}

Analysing the long-term series data for predicting the influence of potential climate changes is an important application of statistics in recent researches. Dettinger (2005) has analysed an historical record of fifty years data to obtain a perspective on flood-generating winter storms in the American River basin. He concluded that the risks for flood generation in the American River are considerable. Hanson et al. (2004) presented a methodology to assess the relationships between climate variability and variations in hydrologic time series in the southwest United States. To demonstrate the application of their method, they analyzed six hydrologic time-series from the Mojave River Basin, California. Their results indicated that climate variability exists in all of the data types and are partially coincident with known climate cycles such as the Pacific Decadal Oscillation and the El Nino-Southern Oscillation.

Montanari et al. (1996) analysed six temporal meteorological series data observations to detect the presence of long memory and linear trends to predict the effects of potential climate change in the cities of Rome and Parma in Italy. Their results indicated that a decreasing trend, although not statistically significant, is present in all six records and that long-term memories are significant in only two series.

Recently Wang et al. (2007) have evaluated Lo's R/S tests, GPH test and the maximum likelihood estimation method implementing in S-Plus (S-MLE), through intensive Monte Carlo simulations for detecting the existence of long-term memory. The subject of long memory (or long-range depen- dence) has been described widely by Baren (1994). In this research, the long-term memory has been investigated using autocorrelation function coefficient (AFC) as described later.

Specifically, in the Great Lakes Basin, both empirical and aerodynamic techniques have been used to estimate evaporation, and studies conducted by Cohen (1986, 1990), Sanderson (1987), and Croley $(1990,2004)$ have found that evaporation would be significantly increased under climate change scenarios. Sanderson and Smith $(1990,1993)$ used the Thornthwaite model and Smith and McBean (1993) used the HELP model and predicted twenty to thirty percent increases in potential evaporation and approximately a $15 \%$ increase in actual evaporation to occur.

Chao (1999) conducted an assessment of the Great Lakes water resources impacts under transient climate change scenarios by an integrated model linking empirical regional climate downscaling, hydrologic and hydraulic models, and GCMs. The transient scenarios show that in the near-term (approximately 20 years) significant changes could occur. Ferris (2005) showed that increased winter and summer air temperatures appear to have the greatest influence on ice formation. The twenty year trend line of the ice duration (1970 1990) on the Great Lakes demonstrated ice formation on the Great Lakes will continue to decrease in total cover if the predictions of global atmospheric warming are correct.

In addition to the above, the latest IPCC assessments (1996 and 2001) indicate there will be an increase of 1.5 to $4.5^{\circ} \mathrm{C}$ in global mean temperature, and a 3 to 15 percent increase in precipitation in response to climate change. Also, the first phase of the IPCC (2007), written by more than 600 scientists and reviewed by another 600 experts and bureaucrats from 154 countries, predicts hotter weather and higher sea level increases in the future. Predictions for the future of global warming in the report are based on 19 computer models, about twice as many as in the past (IPCC, 2007).

In 2001, the panel said the world's average temperature would increase somewhere between 2.5 and 10.4 degrees Fahrenheit (1.4 and 5.7 degrees Centigrade) and the sea level would rise between 4 and 35 inches $(10-90 \mathrm{~cm})$ by the year 2100. The 2007 report will likely have a smaller range of numbers for both predictions (IPCC, 2007).

\subsection{Historical data assembles and data quality}

For this research, mean monthly and mean annual data series for overlake air temperature, overlake precipitation data for the individual Great Lakes and the flow data for their connecting channels (St. Mary's River, St. Clair River, Niagara River, and St. Lawrence River as indicated in Fig. 1) were obtained from the Great Lakes Environmental Research Laboratory (GLERL) of the National Organization for Atmospheric Administration (NOAA-2004). The Great Lakes Environmental Research Laboratory (GLERL) developed a project, under the Environmental Research Laboratories Endangered Data and Increased Access Program, funded under 
the National Environmental Satellite and Data Information Service's Earth System Data and Information Management Program, to develop and archive these lengthy records of hydrologic data for the Great Lakes.

According to Quinn (1983) and Hunter (1993), these data were quality controlled for data reduction errors and original data input errors (such as typographical errors but not for observer errors) combining with existing National Climatic Data Center (NCDC) digital monthly precipitation data from 1948 to 1990 for the stations in Minnesota, Wisconsin, Illinois, Indiana, Michigan, Ohio, Pennsylvania, and New York, and are periodically updated to reflect additional data and to extend the period of record (now until year 2000).

A report prepared by Assel et al. (1995) describes the procedures, equipment, and software used to abstract, reduce, and quality control the data. Overlake precipitation and temperature data are estimated from the records of 3447 stations (Assel et al., 1995), among them 1971 stations were developed between 1962 to 1995 (Fig. 1b). According to Allan and Hinz (2004), "The characterization of flow regimes of rivers of the Great Lakes basin employed a total of 425 gages (259 in U.S., 166 in Ontario)".

Mean monthly precipitation was computed from 19482000 from all available daily data from stations in the Basin or within approximately $0-30 \mathrm{~km}$ of the basin, depending upon the station density near the edge of the Basin. This distance was chosen to assure that the same non-zero Thiessen weights are obtained as if no stations were eliminated. Station data for the U.S. were obtained from the National Climatic Data Center and station data for Canada were obtained from the Atmospheric Environment Service (Assel et al., 1995).

These data have been spatially-weighted using the modified Theissen weighting approach (Croley et al., 2004). As cited in Croley et al. (2004), Quinn and Norton (1982) computed 1930-1947 monthly precipitation using 5-km grid while Croley et al. (2004) used 1-km grid. For the current study, the precipitation data were extracted for the period of 1930-2000.

For the Great Lakes, mean monthly and mean annual overlake air temperature data are available for the period 19482000 (NOAA, 2004). For the streamflows, according to Croley et al. (2004), Lake outflows are determined by direct measurement (for Lakes Superior and Ontario), stage-discharge relationships (for Lakes Michigan, Huron, and St. Clair), or a combination (Lake Erie) and are considered accurate within $5 \%$. For this research, the mean annual flow data were extracted for the period of 1930-2000 to coincide with the precipitation records.

It is noted that a seasonal analysis might also be informative. However, as a preliminary study the mean annual data have been chosen, to avoid of the problem of seasonality, avoiding production of errors due to the values of zero or negative in the data series particularly in the temperatures. As well, the advantage of the annual hydrologic time series is that they present more normality (Sales, 1993). As a result, the mean annual magnitudes are appropriate to give an estimation of the hydrologic parameters for the future.

\subsection{Trend characterization methodology}

\subsubsection{Mann-Kendall test}

There exist a number of parametric and nonparametric methods commonly used for detection of trend (McBean and Rovers, 1998). The non-parametric Mann-Kendall test, which is commonly used for hydrologic data analysis, can be used to detect trends that are monotonic but not necessarily linear. The null hypothesis in the Mann-Kendall test is that the data are independent and randomly ordered. The Mann-Kendall test does not require the assumption of normality, and only indicates the direction but not the magnitude of significant trends (USGS, 2005; Helsel and Hirsch, 1992).

The Mann-Kendall procedure was applied to the time series of annual precipitation, annual mean temperature, and the average annual flows. The computational procedure for the Mann-Kendall test is described below (e.g. also see Adamowski and Bougadis, 2003). Let the time series consist of $n$ data points and $T_{i}$ and $T_{j}$ are two sub-sets of data where $i=1,2,3, \ldots, n-1$ and $j=i+1, i+2, i+3, \ldots, n$. Each data point $T_{i}$ is used as a reference point and is compared with all the $T_{j}$ data points such that:

$\operatorname{sign}(T)=\left\{\begin{array}{rll}1 & \text { for } & \left.T_{j}\right\rangle T_{i} \\ 0 & \text { for } & T_{j}=T_{i} \\ -1 & \text { for } & T_{j}\left\langle T_{i}\right.\end{array}\right.$

The Kendall's S-statistic is computed as:

$S=\sum_{i=1}^{n-1} \sum_{j=i+1}^{n} \operatorname{sign}\left(T_{j}-T_{i}\right)$

The variance for the S-statistic is defined by:

$\sigma^{2}=\frac{n(n-1)(2 n+5)-\sum_{i=1}^{n} t_{i}(i)(i-1)(2 i+5)}{18}$

in which $t_{i}$ denotes the number of ties to extent $i$. The summation term in Eq. (5) is only used if data series contains "tied" values. The test statistic, $Z_{s}$, can be calculated as:

$Z_{s}=\left\{\begin{array}{lll}(S-1) / \sigma & \text { for } & S>0 \\ 0 & \text { for } & S=0 \\ (S+1) / \sigma & \text { for } & S<0\end{array}\right.$

$Z_{s}$ follows a standard normal distribution. Equation (6) is useful for record lengths greater than 10 and if the number of "tied" data is low (Kendall, 1962). The test statistic, $Z_{s}$ is used as a measure of significance of trend. In fact, this test statistic is used to test the null hypothesis, $H_{0}$ : There is no monotonic trend in the data. If $\left|Z_{s}\right|$ is greater than $Z_{\alpha / 2}$, where $\alpha$ represents the chosen significance level (usually 5\%, 
with $Z_{0.025}=1.96$ ), then the null hypothesis is invalid, meaning that the trend is significant.

For use herein, we have used two programs, MINITAB software for calculation of the autocorrelation function coefficient (AFC) between the series with a lag one autocorrelation coefficient $(k)$, and the second, Trend software to calculate the Mann-Kendall magnitudes of $S$ and $Z$ (after Chiew and Siriwardena, 2005).

In this research, first the Mann-Kendall trend test procedure was used to detect the probability of the positive trends between the hydrologic variables. In the next step, the simple regression analysis technique is used to test the slopes of the trend lines, estimation of the prediction value in future, and confidence intervals for precipitation, temperature and streamflows.

\subsubsection{Regression model test}

One of the most useful parametric models to detect the trend is the "Simple Linear Regression" model. The model for $Y$ (e.g. precipitation) can be described by an equation of the form:

$Y=a X+b$

where, $X=$ time (year) $a=$ slope coefficients; and $b=$ leastsquare estimates of the intercept.

The slope coefficient indicates the annual average rate of change in the hydrologic characteristic. If the slope is statistically significantly different from zero, the interpretation is that it is entirely reasonable to interpret there is a real change occurring over time, as inferred from the data. The sign of the slope defines the direction of the trend of the variable: increasing if the sign is positive, and decreasing if the sign is negative.

The method of linear regression requires the assumptions of normality of residuals, constant variance, and true linearity of relationship (Helsel and Hirsch, 1992).In this regard, checking the normality of the data has been done by a special test for normality by using the Ryan-Joiner method (Devore, 2004). The test of Ryan-Joiner can be carry out by MINITAB software by calculation of the Ryan-Joiner (RJ) coefficient. This coefficient will be compared by another coefficient named $\mathrm{Ca}$. If R-J's coefficient is greater than $\mathrm{Ca}$ then the null hypothesis of normality cannot be rejected. The coefficient of $\mathrm{Ca}$ depends on the number of the data and the significance levels of $\alpha$. The values of Ca can be find in the reference of Devore (2004).

\section{Evaluation of the Results}

There are different ways to evaluate the significance of the results such as confidence limits at $95 \%$ levels, sample correlation, R-square and P-value. All these values were calculated in the trend line of this research.
- The $95 \%$ confidence interval of the slope is a range of values, as is the $95 \%$ confidence interval of the intercept. Linear regression can also combine these uncertainties to graph a $95 \%$ confidence interval of the regression line. The best-fit line is solid, and the 95\% confidence interval is shown by two curves surrounding the best-fit line in the figures which follow.

For a population with a sample size of $n$, the confidence interval was calculated by the procedure outlined in Devore (2004):

$$
\hat{Y} \pm t_{(\alpha / 2, n-2)} S_{\hat{Y}}
$$

where $\hat{Y}$ is the mean value of observations, $S_{\hat{Y}}$ the estimated standard deviation of the statistic $\hat{Y}$, and $t_{(\alpha / 2, n-2)}$ a critical value for a $95 \%$ confidence level.

The plotting of the confidence interval for the regression line shows that the $\mathrm{CI}$ is centered at the mean of $X$, namely $X_{\text {mean }}$, and extends out to each side by an amount that depends on the confidence level with a hyperbolic form. This means that the confidence interval depends on the value of $X$. The farther the value of $X$ departs from $X_{\text {mean }}$, the larger is the confidence interval (Devore, 2004). It should be noted that in the presence of autocorrelation, the confidence intervals of the slope of the regression line may widen significantly. Therefore, a slope that is statistically significant under the hypothesis of uncorrelated data may become not significantly different from zero if correlation is properly taken into account.

In addition, in many applications one wishes to predict the value of a variable to be observed at some future time, and obtain an interval of plausible values for the value of $Y$ associated with a future value of $X$. This is possible with calculation of a Prediction Intervals rather than a confidence interval. In this research the prediction intervals refers to the estimation of the hydrologic values of precipitation, temperatures and inflows in 2050 , demonstrate the uncertainty or range associated with these values.

The formula for estimation of prediction intervals is (after Devore, 2004):

$$
\hat{Y} \pm t_{(\alpha / 2, n-2)} \sqrt{S^{2}+S_{\hat{Y}}^{2}}
$$

- The $P$ value is a probability, with a value ranging from zero to one; when $P$ is less than 0.01 , for example, it shows that the trend is significant, so the smaller the $\mathrm{P}$, the more significant the trend (Helsel and Hirsch, 1992).

- The sample correlation coefficient $R$, is a coefficient ranging between -1 and 1 and measures the strength 
Table 2a. Results of statistical trend tests for overlakes precipitation.

\begin{tabular}{lllll}
\hline & \multicolumn{3}{c}{ Mann-Kendall Statistics } \\
\hline Lake & $\begin{array}{l}\text { Autocorrelation } \\
\text { Coefficient }\end{array}$ & Kendall's S & $Z_{S}$ & $\begin{array}{l}\text { Possibility of posi- } \\
\text { tive trend - Signifi- } \\
\text { cance at 5\% level }\end{array}$ \\
\hline Superior & -0.04 & 25 & 0.14 & NO \\
Michigan & 0.02 & 405 & 2.24 & YES \\
Huron & 0.09 & 468 & 2.32 & YES \\
Erie & 0.05 & 405 & 3.00 & YES \\
Ontario & 0.10 & 406 & 3.10 & YES \\
\hline
\end{tabular}

Table 2b. Continued.

\begin{tabular}{|c|c|c|c|c|c|}
\hline \multirow[b]{2}{*}{ Lake } & \multicolumn{5}{|c|}{ Regression Statistics } \\
\hline & Regression Equation & $\begin{array}{l}\text { Slope with } 95 \% \\
\text { Confidence Limits }\end{array}$ & $\begin{array}{l}\text { Statistical Significance } \\
\text { (P value) }\end{array}$ & $\begin{array}{l}\text { Sample } \\
\text { Correlation }\end{array}$ & R-Square \\
\hline Superior & $Y=0.173 X+469$ & $0.173 \pm 1.02$ & $\begin{array}{l}0.45 \\
\text { (Low significance) }\end{array}$ & 0.09 & $0.83 \%$ \\
\hline Michigan & $Y=1.68 X-2493$ & $1.68 \pm 0.95$ & $\begin{array}{l}0.002 \\
\text { (high significance) }\end{array}$ & 0.35 & $12.7 \%$ \\
\hline Huron & $Y=1.25 X-1616$ & $1.25 \pm 0.93$ & $\begin{array}{l}0.0032 \\
\text { (high significance) }\end{array}$ & 0.31 & $9.5 \%$ \\
\hline Erie & $Y=2.73 X-4462$ & $2.73 \pm 1.4$ & $\begin{array}{l}0.0002 \\
\text { (high significance) }\end{array}$ & 0.43 & $18.5 \%$ \\
\hline Ontario & $Y=2.31 X-3694$ & $2.31 \pm 1.02$ & $\begin{array}{l}0.0001 \\
\text { (high significance) }\end{array}$ & 0.48 & $23 \%$ \\
\hline
\end{tabular}

of the linear relationship between $Y$ and $X$. A correlation value close to 0 indicates no association between the variables.

$$
R=\frac{\sum\left(X_{i}-\bar{X}\right)\left(Y_{i}-\bar{Y}\right)}{\sqrt{\sum\left(X_{i}-\bar{X}\right)^{2} \sum\left(Y_{i}-\bar{Y}\right)^{2}}}
$$

- $R$-square $\left(R^{2}\right)$, or the square of the correlation coefficient, is a fraction between 0.0 and 1.0 (unitless). An $R^{2}$ value of 0.0 means that there is not any correlation between $X$ and $Y$ and no linear relationship between $X$ and $Y$. On the other hand, when $R^{2}$ approaches to 1.0 , the correlation becomes strong and with a value of 1.0 all points lie on a straight line.

At this time, there exist a number programs that can calculate these values easily and quickly, including STATISTICA (Statsoft, 2006), STATLETS (NWP, 1997), MINITAB (Devor, 2004) and Excel. For this research the MINITAB and Excel were used to calculate the trend lines, statistical values and plot the figures.

\section{Autocorrelation and long memory in the data}

According to Salas et al. (1993), hydrologic time series are generally autocorrelated. Autocorrelation in some series such as streamflows usually arise from the effects of surface, soil, and groundwater storage. Conversely, annual precipitation is usually uncorrelated.

Autocorrelation, or as sometimes called "serial correlation", refers to the correlation of a time series with its own past and future values separated by " $k$ " lag time units, whereas the simple correlation is the mutual relationship between two or more random variables. Hurst (1951) presented a relationship to show the existence of long memory between tha data by defining a coefficient of $H$ between the (0.5-1) . As presented by (Montanari, 1998):

$\rho_{k} \approx C_{H} k^{2 H-2}$

That $\rho_{k}$ is the autocorrelation coefficient of the process at lag $k, C_{H}$ is a constant and $H$ is called the "Hurst exponent" or the "intensity of long memory" between (0.5-1.0). A value equal to 0.5 means absence of long memory. This relationship shows that the higher the $H$, the higher autocorrelation 

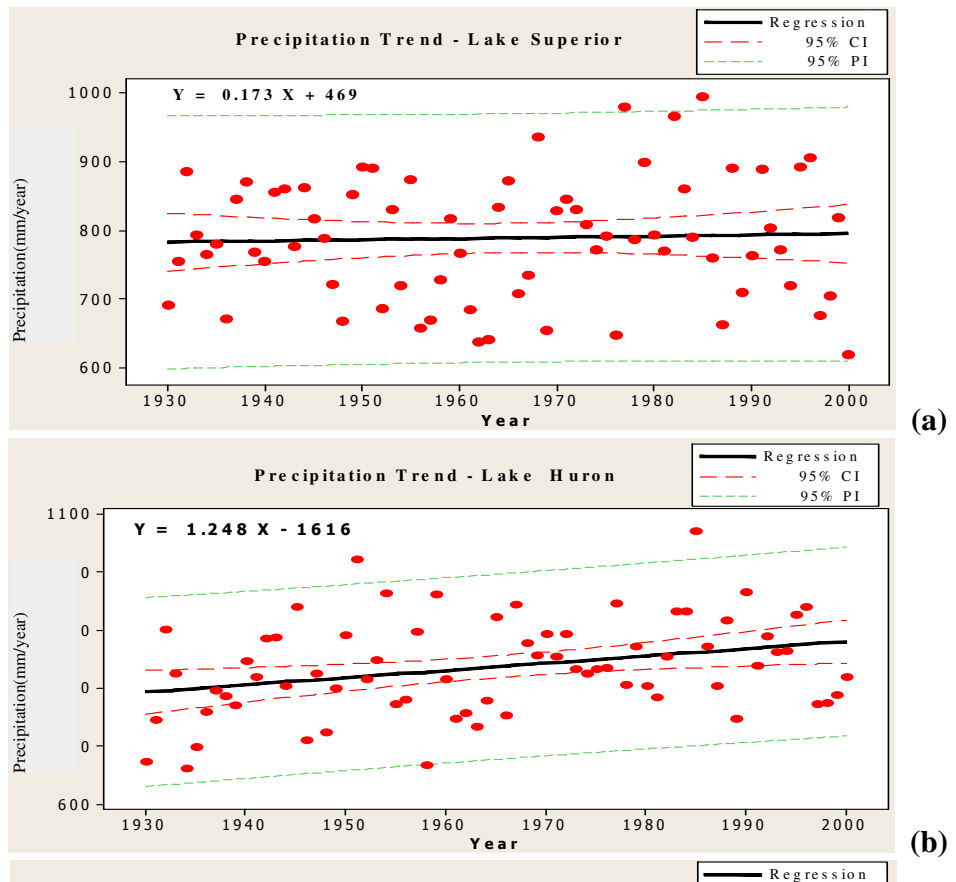

(b)
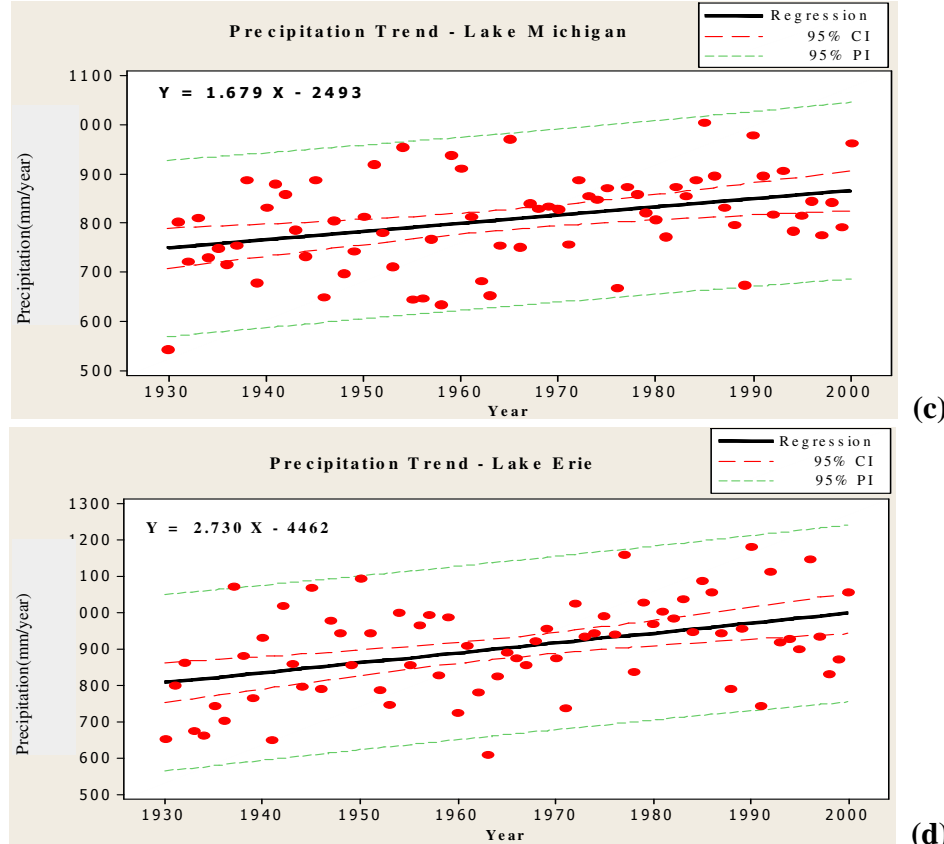

(c)

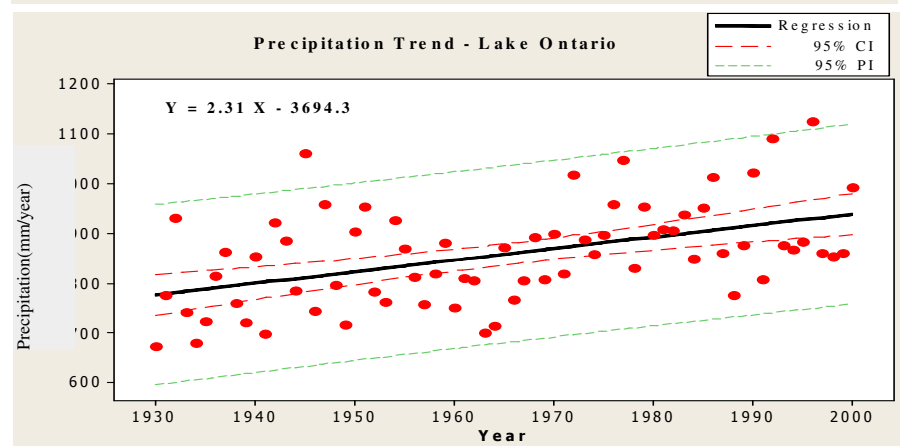

Fig. 2. Trends of precipitations (mm/year) versus time (Year) with 95\% confidence intervals (1930-2000). 
between the data. According to the Montanari "if long memory or autocorrelation is present, it may be more reasonable to suppose that climatological variations are due to a local cycle".

Also the value of $H$ or autocorrelation has an influence in the width of the confidence intervals. The greater the autocorrelation, the greater the confidence limits, and as a result the long memory or high autocorrelation provides more uncertainty on the results obtained by trends procedures (Montanari, 1998).

As well the autocorrelation coefficient can have an influence in the results obtained by the Mann-Kendall test. Khaled and Ramachandra (1998) state that "The null hypothesis for the Mann-Kendall test is that the data are independent and randomly ordered, i.e. there is no trend or serial correlation structure among the observations. However, in many real situations such as hydrology and climatology the observed data are autocorrelated. Cox and Stuart (1955) described that "positive autocorrelation among the observations would increase the chance of significant answer, even in the absence of a trend". Khaled and Ramachandra (1998) indicated that the existence of positive autocorrelation in the data increases the probability of detecting statistically significant trends when actually none exist, and vice versa.

\section{Precipitation, temperature and flow trends}

\subsection{Historical precipitation trends}

The results of precipitation data series by two statistical methods are as follows:

- The Mann-Kendall test: demonstrates an existence of the positive trends for four Lakes of five, Michigan, Huron, Erie and Ontario. For these four lakes there are a small positive autocorrelation respectively $0.02,0.09$, 0.05 and 0.1 and for all of them the value of $Z_{s}$ is greater than $Z_{0.025}$. Meanwhile for Lake of Superior the value of $Z_{s}$ is less than $Z_{0.025}$ with a negative autocorrelation of -0.04 , meaning a positive trend is not demonstrated for Lake Superior (Table 2a).

- The regression test: The Ryan-Joiner method carrying out by MINITAB showed that the data series are normal with the values of coefficient equal to 0.996, 0.994, 0.996, 0.994, 0.991 for Superior, Michigan, Huron, Erie and Ontario Lakes, respectively. The coefficient of $\mathrm{Ca}$ for a data of 70 years and a significance level of $5 \%$ is equal 0.97 (Devore, 2004). As a result, all data are normal because Ryan-Joiner coefficient for all series is greater than $\mathrm{Ca}$, and hence the null hypothesis of normality cannot be rejected.

The long-term precipitation data (1930-2000) for the individual Great Lakes are plotted as annual precipitation versus time in Fig. 2a through e. The slopes of the trend lines are highly significant from both the regression modeling and using the Mann-Kendall statistic and low significance for Lake Superior, as summarized in Table $2 \mathrm{~b}$. These results demonstrate there is sufficient evidence to indicate (on the basis of 1930-2000 period) an increasing trend in precipitation for four of the five Great Lakes. Interpretation of the statistical coefficients shows that:

- Lake Superior: Since the P-value for the slope is greater or equal to 0.05 , there is not a statistically significant relationship between Precipitation and Year at the 95\% confidence level. The $95 \%$ confidence limits of slope $(0.173 \pm 1.02)$ include a value of zero for slope. The Rsquare statistic indicates that the model, as fitted, explains $0.83 \%$ of the variability in precipitation. The correlation coefficient equals 0.09 , indicating a relatively weak relationship between the variables.

- Lakes of Michigan, Huron, Erie, and Ontario: Since the P-value for the slope is less than 0.01, there is a statistically significant relationship between "Precipitation" and "Year" at the $95 \%$ confidence level for all of these Lakes. There is no value of zero for the slopes in the $95 \%$ of confidence limits. The R-Square statistic indicates that the model as fitted explains respectively $12.7 \%, 9.5 \%, 18.5 \%$ and $23 \%$ of the variability in precipitation for these four lakes, all representing statistically significant relationships.

The regression tests show the same results as those obtained by the Mann-Kendall test.

\subsection{Trends in temperature}

- The Mann-Kendall test: results from application to the temperature series are presented in Table 3a. All demonstrate small positive autocorrelations and for all five lakes the value of $Z_{s}$ is less than 1.96, meaning the probability of positive trend is very low.

- The regression test: The Ryan-Joiner method showed that the data series are normally distributed with the values of coefficient equal to $0.97,0.98,0.97,0.97,0.97$ for Superior, Michigan, Huron, Erie and Ontario Lakes, respectively. The coefficients of $\mathrm{Ca}$ for 53 years of record and a significance level of 5\% are equal 0.96 (Devore, 2004). As a result, because the Ryan-Joiner coefficient for all series is greater than $\mathrm{Ca}$, the null hypothesis of normality cannot be rejected.

Average annual trends of overlake temperature versus time (1948-2000), are illustrated in (Fig. 3a through e). The significance of the long-term temperature data for the individual Great Lakes were tested with the results as summarized in the Table 3b.

None of the trends for temperature were identified as statistically significant at the $5 \%$ level although the best estimates of the slopes of the regression lines were all positive. 
Table 3a. Results of statistical trend tests for overlakes temperatures.

\begin{tabular}{lllll}
\hline & & \multicolumn{3}{c}{ Mann-Kendall Statistics } \\
\hline Lake & $\begin{array}{l}\text { Autocorrelation } \\
\text { Coefficient }\end{array}$ & Kendall's S & $Z_{S}$ & $\begin{array}{l}\text { Possibility of posi- } \\
\text { tive trend - Signifi- } \\
\text { cance at 5\% level }\end{array}$ \\
\hline Superior & 0.20 & -48 & 0.50 & NO \\
Michigan & 0.14 & -84 & 0.88 & NO \\
Huron & 0.11 & -136 & 1.40 & NO \\
Erie & 0.29 & -78 & 0.81 & NO \\
Ontario & 0.15 & -44 & 0.46 & NO \\
\hline
\end{tabular}

Table 3b. Continued.

\begin{tabular}{|c|c|c|c|c|c|}
\hline \multirow[b]{2}{*}{ Lake } & \multicolumn{5}{|c|}{ Regression Statistics } \\
\hline & Regression Equation & $\begin{array}{l}\text { Slope with } 95 \% \\
\text { Confidence Limits }\end{array}$ & $\begin{array}{l}\text { Statistical Significance } \\
\text { (P value) }\end{array}$ & $\begin{array}{l}\text { Sample } \\
\text { Correlation }\end{array}$ & R-Square \\
\hline Superior & $Y=0.0163 X-28.19$ & $0.016 \pm 0.015$ & $\begin{array}{l}0.05 \\
\text { (low significance) }\end{array}$ & 0.28 & $8 \%$ \\
\hline Michigan & $Y=0.001 X+5.84$ & $0.001 \pm 0.010$ & $\begin{array}{l}0.87 \\
\text { (low significance) }\end{array}$ & 0.02 & $0.05 \%$ \\
\hline Huron & $Y=0.0004 X+6.05$ & $0.0004 \pm 0.009$ & $\begin{array}{l}0.97 \\
\text { (low significance) }\end{array}$ & 0.04 & $0.2 \%$ \\
\hline Erie & $Y=0.007 X-5.48$ & $0.007 \pm 0.017$ & $\begin{array}{l}0.26 \\
\text { (low significance) }\end{array}$ & 0.17 & $3 \%$ \\
\hline Ontario & $Y=0.005 X-1.89$ & $0.005 \pm 0.020$ & $\begin{array}{l}0.41 \\
\text { (low significance) }\end{array}$ & 0.12 & $1.5 \%$ \\
\hline
\end{tabular}

The R-Square statistic indicates that the model as fitted explains $8 \%, 0.05 \%, 0.2 \%, 3 \%$ and $1.5 \%$ of the variability in Temperature (Table 3b). The simple correlation coefficient for all five Lakes respectively equals $0.28,0.024,0.04$, $0.17,0.12$, indicating there is no statistically significant relationship between temperature and time. The regression tests confirm the results obtained by the Mann-Kendall test.

\subsection{Trends in measured flows}

Flow data were analyzed for four locations at various points along the Great Lakes system namely (I) St. Mary's River, (II) St. Clair River, (III) Niagara River, and (IV) St. Lawrence River, as identified in Fig. 1a. These locations represent the sequential locations within the Great Lakes Watershed.

- The Mann-Kendall results test: The Mann-Kendall trend test results are as summarized in Table 4a. The autocorrelation coefficients for St. Mary's, St. Clair, Niagara, and St.Lawrence are 0.38, 0.8, 0.82 and 0.8, respectively. Except for the St. Mary's river, the value of $Z_{S}$ for three other rivers is greater than 1.96 , and hence demonstrates there are statistically significant positive trends for them.

- The regression results test: The Ryan-Joiner method showed that the data series are normal with the values of coefficient equal to $0.99,0.993,0.991,0.995$ for St. Mary's River, St. Clair River, Niagara River, and St. Lawrence River, respectively. The coefficient of $\mathrm{Ca}$ for a number data of 70 ears and a significance level of $5 \%$ is equal 0.97 . As a result, all data are normal because Ryan-Joiner coefficient for all series is greater than $\mathrm{Ca}$, as the null hypothesis of normality cannot be rejected.

The flow magnitudes over time are plotted in Fig. 4 (4a: St. Mary's River, 4b: St. Clair River, 4c: Niagara River, and 4d: St. Lawrence River). In order to verify whether there is a significant linear trend in the data, the resulting slopes with relative confidence limits for 1930-2000 are given in Table $4 \mathrm{~b}$ and demonstrate the following results:

- St. Mary (Outlet of Lake Superior): Since the P-value for the slope is greater than or equal to 0.01 , there is not 


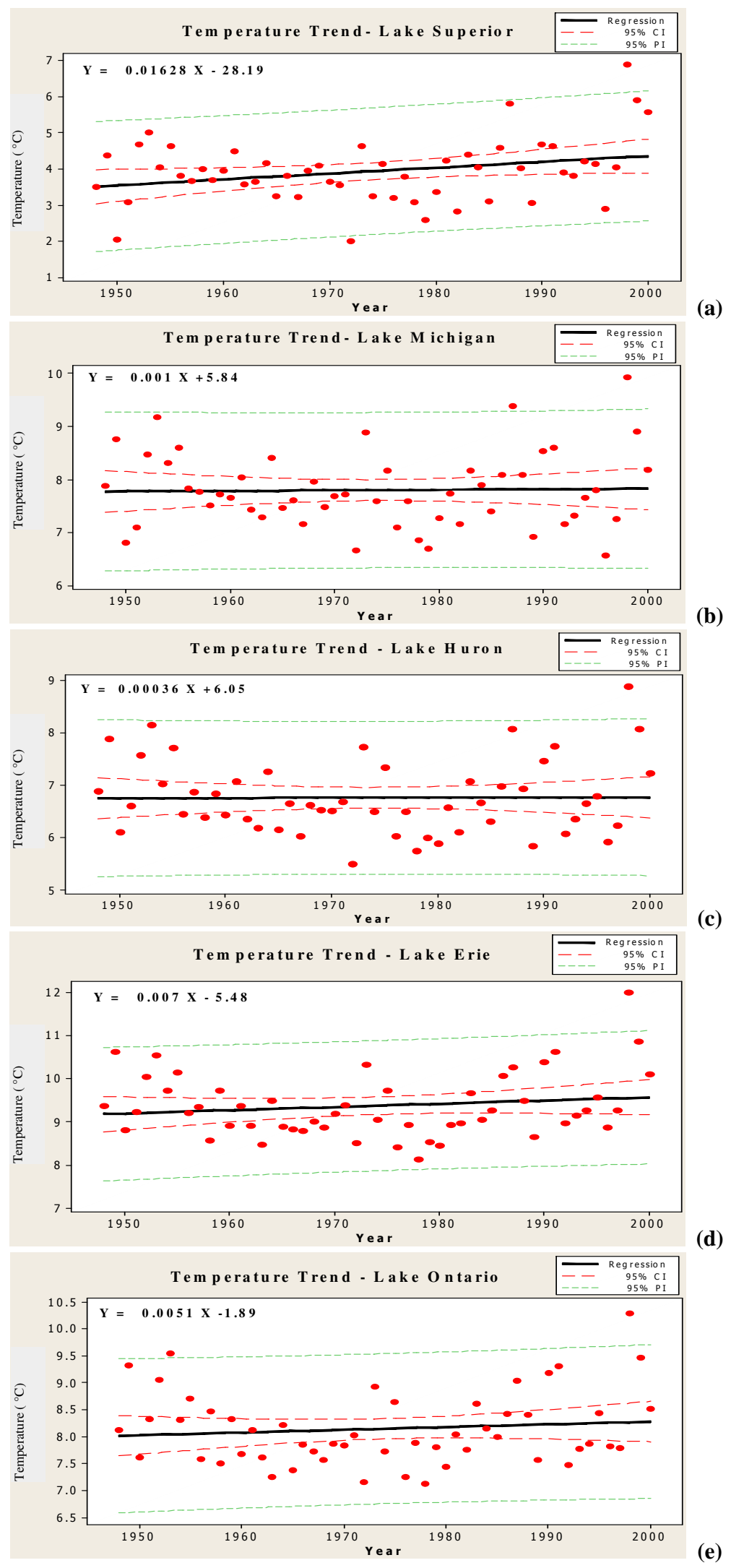

Fig. 3. Trends of annual average temperatures (degree Celsius) versus time (Year) with 95\% confidence intervals (1948-2000). 
Table 4a. Results of statistical trend tests for time series of flows in the rivers.

\begin{tabular}{|c|c|c|c|c|}
\hline \multirow[b]{2}{*}{ River } & \multirow[b]{2}{*}{$\begin{array}{l}\text { Autocorrelation } \\
\text { Coefficient }\end{array}$} & \multicolumn{3}{|c|}{ Mann-Kendall Statistics } \\
\hline & & Kendall's S & $Z_{s}$ & $\begin{array}{l}\text { Possibility of posi- } \\
\text { tive trend - Signifi- } \\
\text { cance at } 5 \% \text { level }\end{array}$ \\
\hline St. Mary's & 0.38 & 213 & 1.32 & NO \\
\hline St. Clair & 0.80 & 777 & 4.83 & YES \\
\hline Niagara & 0.82 & 825 & 5.13 & YES \\
\hline St. Lawrence & 0.80 & 826 & 5.10 & YES \\
\hline
\end{tabular}

Table 4b. Continued.

\begin{tabular}{|c|c|c|c|c|c|}
\hline \multirow[b]{2}{*}{ River } & \multicolumn{5}{|c|}{ Regression Statistics } \\
\hline & Regression Equation & $\begin{array}{l}\text { Slope (with } 95 \% \\
\text { Confidence Limits } \\
\text { of Slope) }\end{array}$ & $\begin{array}{l}\text { Statistical Significance } \\
\text { (P value) }\end{array}$ & $\begin{array}{l}\text { Simple } \\
\text { Correlation }\end{array}$ & R-Square \\
\hline St. Mary's & $Y=0.84 X+553$ & $0.84 \pm 4.10$ & $\begin{array}{l}0.20 \\
\text { (Low significance) }\end{array}$ & 0.17 & $2.8 \%$ \\
\hline St. Clair & $Y=13.13 X-20559$ & $13.13 \pm 5.50$ & $\begin{array}{l}3 \times 10^{-7} \\
\text { (high significance) }\end{array}$ & 0.55 & $31 \%$ \\
\hline Niagara & $Y=20.75 X-34908$ & $20.7 \pm 6.50$ & $\begin{array}{l}5 \times 10^{-8} \\
\text { (high significance) }\end{array}$ & 0.60 & $35 \%$ \\
\hline St. Lawrence & $Y=25.54 X-43119$ & $25.5 \pm 8.30$ & $\begin{array}{l}3 \times 10^{-8} \\
\text { (high significance) }\end{array}$ & 0.60 & $36 \%$ \\
\hline
\end{tabular}

a statistically significant relationship between Flow and Year at the $95 \%$ confidence level. The $95 \%$ confidence limits of slope $(0.84 \pm 4.1)$ include a value of zero for slope. The R-Square statistic indicates that the model as fitted explains $2.8 \%$ of the variability in Flow and the simple correlation coefficient equal 0.17 , indicating a relatively weak relationship between the variables.

- St. Clair (Outlet of Lake Huron), Niagara (Outlet of Lake Erie), St. Lawrence (Outlet of Lake Ontario): Since the P-value for the slope is less than 0.01, there is a statistically significant relationship between Flow and Year at the 95\% confidence level for all these sets of flow. There is no value of zero for the slopes in the 95\% confidence limits. The R-Square statistic indicates that the model as fitted explains respectively $31 \%, 35 \%$ and $36 \%$ of the variability in flow.

The regression tests of flows versus time are adjusted with the result with those obtained by the Mann-Kendall test.

\section{Comparison of historical trend projections and GCM predictions}

If the historical trends continue, the magnitudes of precipitation and flow can be assessed for future years, and hence provide a comparison with the projections using the GCMs. It is noted that scenarios of climate change have typically been structured as percent change from the 1960-2000 period, as a means of establishing a baseline relative to, for example, the year 2050, the projected year in which there is considered the potential for a doubling of $\mathrm{CO}_{2}$ in the atmosphere (e.g. after Lofgren et al., 2002). In this context, trend extrapolation of the historical data using the regression equations for each of precipitation, temperatures, and flows, are summarized in Tables 5 through 7, respectively.

\subsection{Prediction of precipitation changes to year 2050}

Based on the observed historical records, precipitation rates are significantly increasing over the Great Lakes. The rate of increase in precipitation over the 70 years period (19302000) is alarming. From Table 5, if the trends apparent over the 1930-2000 time period continue, the predicted increases in precipitation with their uncertainties at the Lakes 


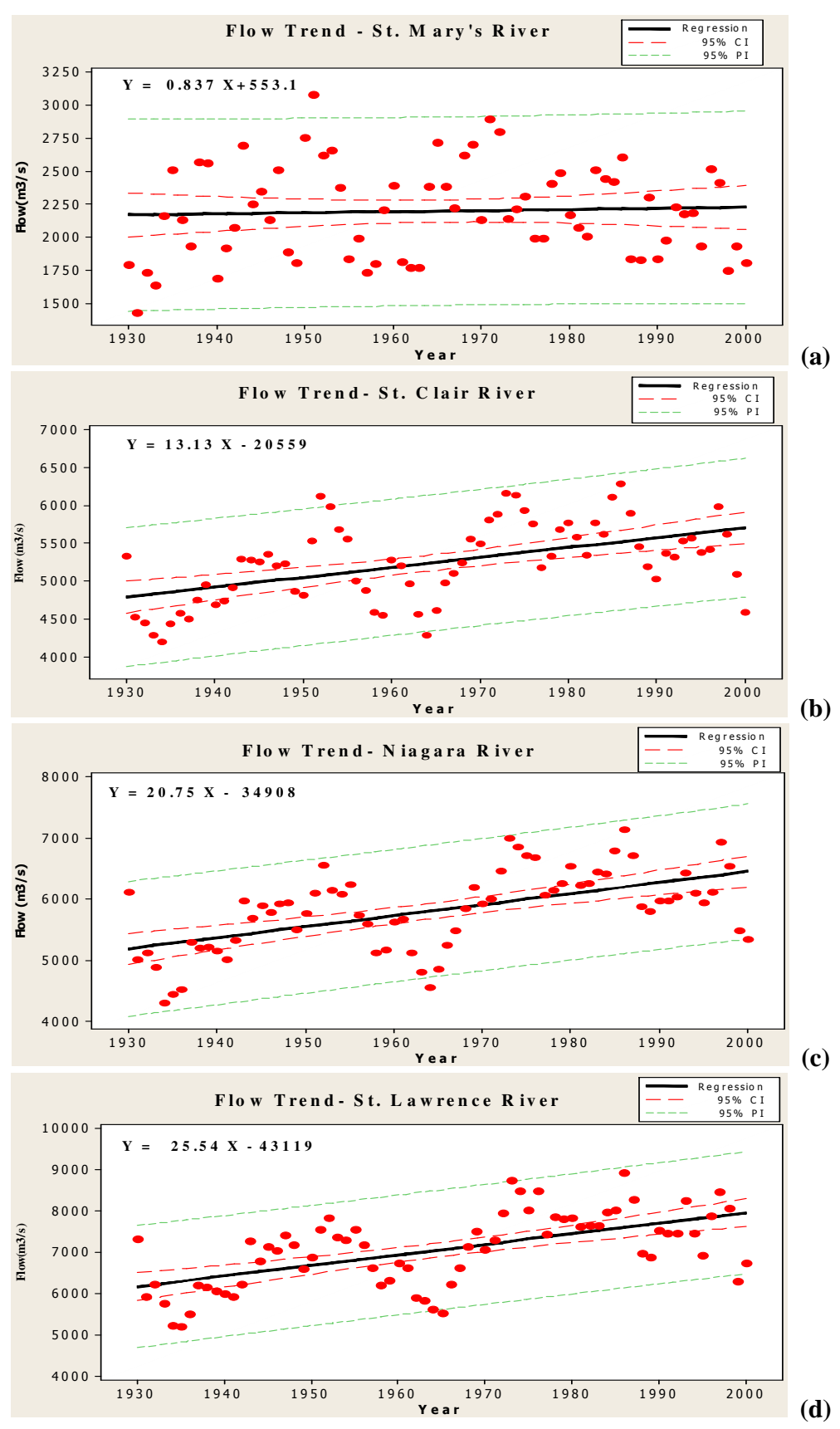

Fig. 4. Trends of annual average river flows at various locations within the Great Lakes watersheds versus time(Year), with $95 \%$ confidence intervals (1930-2000).

of Superior, Michigan, Huron, Erie, and Ontario till 2050 are $4.1 \% \pm 4.9 \%, 12.50 \% \pm 4.5 \%, 10.9 \% \pm 4.8 \%, 21.8 \% \pm 8 \%$ and $19 \% \pm 5 \%$, respectively.

GCMs are being used to develop future scenarios under changed climate conditions (Mortsch et al., 2000). For illustration purposes, the GCM predictions for future changes in precipitation for Lake Superior, Lake Michigan and Lake Huron (the latter two combined to Michigan/Huron) from
Lofgren (2002) are plotted in Fig. 5a and b. Lofgren et al. (2002) results show that different GCMs produce significantly different predictions; they used outputs from two different types of GCMs namely the equilibrium models (GISS, GFDL, OSU, and CCC1) and the transient models (CGCM1, HadCM2, GFTR2, HCTR2, MOTR2, and CCTR2).

In addition to the GCM predictions, also plotted on Fig. 5a and $\mathrm{b}$ are extrapolations from the observed, historical trends. 
Table 5. Predicted changes in precipitation to 2050 from historical trend projections and associated uncertainty.

\begin{tabular}{lllll}
\hline Lake & $\begin{array}{l}\text { Average Precipitation } \\
\text { (mm/year) }\end{array}$ & $\begin{array}{l}\text { Trend Extrapolation for } \\
\text { Precipitation to 2050 } \\
\text { (mm/year) }\end{array}$ & $\begin{array}{l}\text { Uncertainty of Precipitation } \\
\text { to 2050 } \\
\text { (mm/year) }\end{array}$ & $\begin{array}{l}\text { Percentage Change } \\
\text { in Precipitation } \\
(\%) \text { with uncertainty }\end{array}$ \\
\hline Superior & 792 & 825 & $825 \pm 40$ & $4.1 \% \pm 4.9 \%$ \\
Michigan & 834 & 938 & $938 \pm 43$ & $12.5 \% \pm 4.5 \%$ \\
Huron & 853 & 947 & $947 \pm 40$ & $10.9 \% \pm 4.8 \%$ \\
Erie & 932 & 1135 & $1135 \pm 75$ & $21.8 \% \pm 8 \%$ \\
Ontario & 886 & 1055 & $1055 \pm 44$ & $19 \% \pm 5 \%$ \\
\hline
\end{tabular}

Table 6. Comparison of future temperatures(degree Celsius) for projections from historical trends and GCMs.

\begin{tabular}{lllllll}
\hline Lake & $\begin{array}{l}\text { Average Temperature } \\
\left({ }^{\circ} \mathrm{C}\right) \text { of Base Case } \\
(1960-2000)\end{array}$ & & Projected Temperature $\left({ }^{\circ} \mathrm{C}\right)$ for 2050 & \\
& & & & & \\
& & & From Historical \\
Trends Projections $\left({ }^{\circ} \mathrm{C}\right)$ & & & \\
\hline & & & GISS & GFDL & OSU \\
\hline Superior & 3.70 & 5.20 & 6.60 & 9.50 & 5.70 \\
Michigan & 7.70 & $(1.50)$ & $(2.90)$ & $(5.80)$ & $(2.00)$ \\
& & 7.90 & 11.90 & 13.4 & 10.70 \\
Huron & 6.60 & $(0.20)$ & $(4.20)$ & $(5.70)$ & $(3.00)$ \\
Erie & 9.10 & 6.90 & 9.90 & 11.70 & 8.60 \\
& & $(0.30)$ & $(3.30)$ & $(5.10)$ & $(2.00)$ \\
Ontario & 8.00 & 9.90 & 13.80 & 14.80 & 12.50 \\
& & $(0.80)$ & $(4.70)$ & $(5.70)$ & $(3.40)$ \\
\hline Average & 7.02 & 8.37 & 11.80 & 13.10 & 10.40 \\
& & $(0.37)$ & $(3.80)$ & $(5.10)$ & $(2.40)$ \\
\hline
\end{tabular}

Note: values within parentheses represent the change in projected temperature compared to the Base Case mean (1960-2000).

${ }^{a}$ Values extracted from Croley (1990)

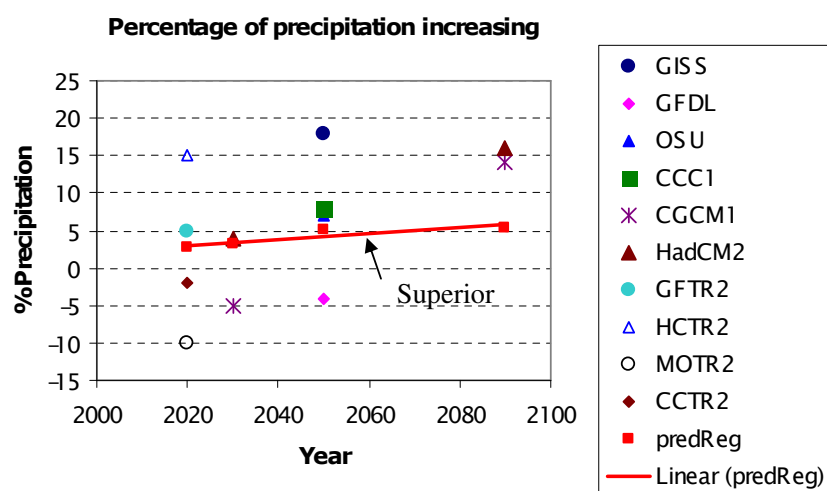

Fig. 5a. Comparison of results of GCMs models by Lofgren et al. (2002) with predicted model in Lake of Superior.

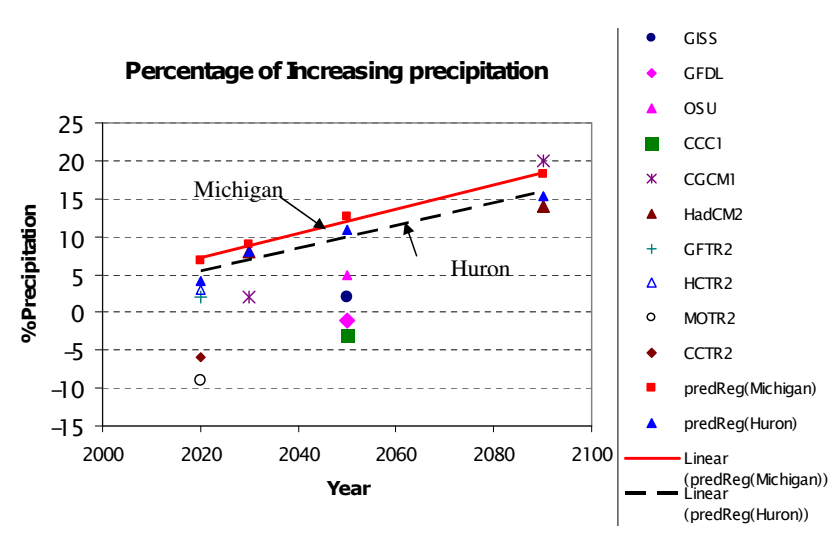

Fig. 5b. Comparison of results of GCMs models by Lofgren et al. (2002) with predicted model in Lake Michigan and Lake Huron. 
Table 7. Predicted changes in flows to 2050 from historical trend projections and uncertainty associated with.

\begin{tabular}{lllll}
\hline River & $\begin{array}{l}\text { Average Annual Flow } \\
\left(\mathrm{m}^{3} / \mathrm{s}\right)\end{array}$ & $\begin{array}{l}\text { Trend extrapolation } \\
\text { for Flows to 2050 } \\
\left(\mathrm{m}^{3} / \mathrm{s}\right)\end{array}$ & $\begin{array}{l}\text { Uncertainty for } \\
\begin{array}{l}\text { Flows to 2050 } \\
\left(\mathrm{m}^{3} / \mathrm{s}\right)\end{array}\end{array}$ & $\begin{array}{l}\text { Predicted Percentage } \\
\text { Change }(\%)- \\
\text { with uncertainty }\end{array}$ \\
\hline $\begin{array}{l}\text { St. Mary } \\
\text { (Outlet of Lake Superior) }\end{array}$ & 2125 & 2270 & $2270 \pm 180$ & $7.0 \% \pm 8.2 \%$ \\
$\begin{array}{l}\text { St. Clair } \\
\text { (Outlet of Lake Huron) }\end{array}$ & 5441 & 6357 & $6357 \pm 227$ & $17.0 \% \pm 4.0 \%$ \\
$\begin{array}{l}\text { Niagara } \\
\text { (Outlet of Lake Erie) }\end{array}$ & 6063 & 7610 & $7610 \pm 275$ & $25.5 \% \pm 5.0 \%$ \\
$\begin{array}{l}\text { St. Lawrence } \\
\text { (Outlet of Lake Ontario) }\end{array}$ & 7400 & 9238 & $9238 \pm 365$ & $25.5 \% \pm 5.0 \%$ \\
\hline
\end{tabular}

Table 8a. Magnitude of increasing percentages of precipitation by GCMs models(Lofgren-2002) and trend line for Lake Superior (related to Fig. 5a).

\begin{tabular}{cccccccccccc}
\hline & GISS & GFDL & OSU & CCC1 & CGCM1 & HadCM2 & GFTR2 & HCTR2 & MOTR2 & CCTR2 & PredReg. \\
\hline 2020 & & & & & & & 5 & 15 & -10 & -2 & 2.7 \\
2030 & & & & & -5 & 4 & & & & & 3.2 \\
2050 & 18 & -4 & 7 & 8 & & & & & & & 4.1 \\
2090 & & & & & 14 & 16 & & & & & 5.4 \\
\hline
\end{tabular}

Table 8b. Magnitude of increasing percentages of precipitation by GCMs models(Lofgren-2002) and trend line for Lake Michigan and Huron (related to Fig. 5b).

\begin{tabular}{ccccccccccccc}
\hline & GISS & GFDL & OSU & CCC1 & CGCM1 & HadCM2 & GFTR2 & HCTR2 & MOTR2 & CCTR2 & $\begin{array}{c}\text { PredReg. } \\
\text { (Michigan) }\end{array}$ & $\begin{array}{c}\text { PredReg. } \\
\text { (Huron) }\end{array}$ \\
\hline 2020 & & & & & & & 2 & 3 & -9 & -6 & 6.9 & 4.2 \\
2030 & & & & & 2 & 8 & & & & & 8.9 & 8.0 \\
2050 & 2 & -1 & 5 & -3 & & & & & & & 12.6 & 10.9 \\
2090 & & & & & 20 & 14 & & & & & 18.2 & 15.4 \\
\hline
\end{tabular}

Note:

GISS - Goddard Institute for Space Studies;

GFDL - Geophysical Fluid Dynamics Laboratory;

OSU - Oregon State University;

CCC1 - Canadian Centre for Climate Modeling and Analysis ver.1. CGCM1 (Coupled General Circulation Model ver.1), GFTR2, HCTR2, CCTR2 are the transient models of CCC, GFDL, United Kingdom Meteorological Office's Hadley Center, and CCC respectively.

PredReg. - Predicted change by using Regression analysis.

Tables $8 \mathrm{a}$ and $\mathrm{b}$ show the magnitudes of increasing percentages of precipitation for GCMs by Lofgren (2002) and calculated trend lines. As illustrated in Fig. 5a, for Lake Superior, compared to the prediction by regression, some GCMs overestimate the change in precipitation while some underestimate. For Fig. 5b, for Michigan/Huron Lakes, trend predictions by the regression lines exceed GCM model predictions. It is interesting to note that others have also reported significant differences in precipitation differentials where Lenters
(2000) reported, "It is not clear why Lakes Superior and Michigan-Huron are behaving differently, but it may be related to differences in regional climate."

In addition, there is substantial uncertainty with the GCM predictions; for instance, Mortsch et al. (2005) emphasize that "there is no way of determining which climate change scenario is the "best" prediction of the future climate, the "worst case scenario", or the "average" potential change in climate. Ideally, a range of possible future climates and 
their implications should be explored through the use of a number of climate change scenarios". However, precipitation trend characterization is challenging since precipitation varies substantially across space and time, and hence it is difficult to predict a significant long-term change (Mortsch et al., 2000). Nevertheless, the technical literature reveals there is evidence of increasing trend of precipitation; Mortsch et al. (2000) reported annual precipitation trends for regions of Canada near the Great Lakes region are significantly increasing. As well, Filion (2000) cited that Coulson's (1997) results indicate a precipitation increase of $7-18 \%$ in northern British Columbia.

\subsection{Prediction of temperature changes to year 2050}

According to IPCC (2001), global temperatures are expected to increase by $1.5^{\circ} \mathrm{C}$ to $4.5^{\circ} \mathrm{C}$, as opposed to the trend extrapolation of historical data of $0.63^{\circ} \mathrm{C}$ in the Great Lakes (from Table 6). Upon analyzing the data for the period 1895-1999, Mortsch et al. (2000) suggested that the annual average temperature for Canada has increased by a statistically significant $1.3^{\circ} \mathrm{C}$, although the increase is not consistent throughout the time span.

The continuation of change in temperature from the observed records can be compared with GCMs prediction of future temperature. The GCMs predictions are consistently higher than those extrapolated from the historical data as listed in Table 6. Even different GCM predictions are demonstrated as varying amongst themselves by substantial amounts, indicating there are substantial levels of uncertainty associated with temperature predictions.

\subsection{Prediction of flows to year 2050}

Based on the observed historical records, annual precipitation rates are significantly increasing over the Great Lakes. This increase in precipitation can lead to increased streamflows in the Great Lakes system (as apparent from Table 5). The increase in streamflows over the 70 years period (19302000 ) is substantial. From Table 7, if the trends apparent over the 1930-2000 time period continue, the rate of predicted increases in streamflows with their uncertainties at the outlet of Lake of Superior, Lake Huron, Lake Erie, and Lake Ontario till 2050 is $7.0 \% \pm 8.24 \%, 17.0 \% \pm 4 \%, 25.5 \% \pm 5 \%$, and $25.5 \% \pm 5 \%$, respectively.

\section{Discussion: uncertainty of the results}

Statistical and mathematical models can be always an approximate description of reality, and the treatment of uncertainty is a basic issue in all hydrologic modeling and climate change research.

It should be mentioned here the detection and estimation of autocorrelation (presence of long memory) has become an important tool in time series analysis.
The presence of the autocorrelation influences the confidence limits of the slope of the regression line. It means a slope that is statistically significant under the hypothesis of uncorrelated data may become not significantly different from zero if autocorrelation is properly taken into account (Montanari, 1996 and Baren, 1994).

In this regard, the uncertainty of the results was estimated by $95 \%$ confidence intervals and prediction intervals in 2050 . As a result, the results of precipitation and temperatures data series in Great Lakes with a low autocorrelation might be due to impact of global warming and climate change but on the other hand, the results of streamflows with high values of autocorrelation in four river cases have more uncertainty in the confidence intervals, and demonstrate that they might be due to a local cycle and physical changes in the basins.

Studies demonstrate that there is a considerable ongoing impact of climate change on water resources, but the intensity of this impact depends on conditions of climate change in the future. Increases in precipitation and temperature could result in dire consequences on water quantity and quality. Precipitation directly translates into runoff, and the regions that experience significant increases in precipitation are likely to have increases in runoff and streamflows although land use changes may also influence runoff peaks. One of the major impacts of climate change would be the changes in frequency and magnitude of extreme hydrologic events (e.g. more intensive rainfall events). Incidence of heavier rainfall events could result in more rapid runoff and greater flooding. As well, heavier rainfall may cause deterioration of water quality. Increased rainfall intensity and high magnitude of floods may result in increased erosion of the land surface and the stream channels, higher sediment loads, and increased loadings of nutrient and contaminants.

\section{Conclusions}

Long-term historical data series of precipitation, temperature, and streamflows in the Great Lakes system using simple linear regression analysis and non-parametric Mann-Kendall trend test, demonstrate statistically significant increases in some precipitation and streamflows over the period 19302000. It can be seen, in all series, increasing trends are positive. In some modeling, particularly for the temperatures, the regression line does not show statistical significance.

Temperature trends were not found to be statistically significant (at 5\% level) for any of the five Great Lakes, although the best fit line shows a gentle increasing slope, an average increase of $0.63^{\circ} \mathrm{C}$ in the basin and less in magnitude than the GCM predictions.

Flows in the St. Mary's River (outlet of the Lake Superior) show a gentle increasing trend, whereas flows in the connecting channels at St. Clair River, Niagara River, and St. Lawrence River illustrate statistically significant increases (at 95\% confidence limits) trends. Because of the 
high autocorrelation coefficients in the streamflow data, the uncertainties of the prediction of flows to 2050 are considerable.

The presence of significant positive trends in historical precipitation, and comparable levels as predicted by the GCMs, indicate that the hydrologic changes being incurred in the some Lakes of the Great Lakes system may be attributable to climate change. The prediction results of research demonstrate that until 2050, the increasing trends of the historical data may sustain their changes at the same rate. Accordingly, it might be said that until 2050, the slope of the changes may behave according to the suggested equations and slopes.

Acknowledgements. The assistance from Khurshid Anwar in the assembly of the hydrologic data is acknowledged. Additionally, the authors also thank the editor of the HESS journal and the referees for their critical, but highly constructive comments that have considerably improved the paper.

Edited by: H. H. G. Savenije

\section{References}

Adamowski, K. and Bougadis, J.: Detection of trends in annual extreme rainfall, Hydrol. Processes, 17, 3547-3560, 2003.

Allan, D. and Hinz, L.: An assessment of flows for rivers of the Great Lakes Basin, School of Natural Resources \& Environment, University of Michigan, Ann Arbor MI 48109-1115, 2004.

Assel, A. R., Sellinger, C. E., Meyer, D. E., and Kelly, R. N.: Great Lakes States monthly precipitation Data, Beginning Of Record To 1990, NOAA Technical Memorandum ERL GLERL86, Michigan, 1995

Baren, J.: Statistics for long memory processes, Chapman and Hall, New York, USA, 315 pp., 1994.

Beeton, A. M.: Large Freshwater Lakes: present state, trends, and future, Environmental Conservation, 29(1), 21-38, 2002.

Boer, G. J., McFarlane, N. A., and Lazare, M.: Greenhouse Gas-induced climate change simulated with the CCC secondgeneration General Circulation Model, J. Climate Change, 5, 1045-1077, 1992.

Boer, G. J., Flato, G. M., Reader, M. C., and Ramsden, D.: A transient climate change simulation with historical and projected greenhouse gas and aerosol forcing, experimental design and comparison with the instrumental record for the 20th century, Clim. Dynam., 16, 405-425, 2000.

Chao, P. T.: Great Lakes water resources, climate change impact analysis with transient GCM scenarios, 35(6), 1499-1507,1999.

Chiew, F. and Siriwardena, L.: Manual of trend/change detection software, CRC for Catchment Hydrology, Australia, 2005, available at: www.toolkit.net.au/trend, last access: July 2007.

Cohen, S.: Impacts of C02-induced climatic change on water resources in the Great Lakes Basin, J. Climate Change, 8, 135-153, 1986.

Cohen, S.: Methodological issues in regional impacts research, Proceedings of Conference on Climate Change, Implications for Water and Ecological Resources, Department of Geography, Occasional Paper No. 11, University of Waterloo, 342 pp., 1990.
Coulson, C. H.: The Impacts of climate change on river and stream flow in British Columbia and southern Yukon, in: Canada Country Study, Vol. I, edited by: Taylor, E. and Taylor, B., 5-1 to 5-11, 1997.

Croley, T. E.: Laurentian Great Lakes Double- $\mathrm{CO}_{2}$ climate change hydrological impacts, J. Climatic Change, 17(1), 27-47, 1990.

Croley, T. E., Hunter, T. S., and Martin, S. L.: Great Lakes monthly hydrologic Data, Internal Report, Publications, NOAA, Great Lakes Environmental Research Laboratory, 13, Michigan, USA, 2004.

De Loë, R. C. and Kreutzwiser, R. D.: Climate variability, climate change and water resource management in the Great Lakes, J. Climatic Change, 45, 163-179, 2000.

Dettinger, M. D.: A Long term (50 Yr.) historical perspective on flood-generating winter storms in the American river basin, Proceedings of California Extreme Precipitation Symposium, 6277, 2005.

Devore, J. L.: Probability and Statistics for Engineering and Sciences, Sixth Edition, Brooks/Cote, Thomson Learning publication, Canada, 2004

Dulmer, J. M., Pebbles, V., and Gannon, J.: North American Great Lakes, Lake management initiative regional workshop for Europe, Central Asia and the Americas, Saint Michael's College, Vermont, USA, 2003.

Ferris, G.: State of the Great Lakes Basin, ice duration on the Great Lakes, Environment Canada, 2005.

Filion, Y.: Climate Change: implications for Canadian water resources and hydropower production, Canadian Water Resources J., 25(3), 255-269, 2000.

Gleick, P.: Methods for evaluating the regional hydrologic impacts of global climatic changes, J. Hydrol., 88, 97-116, 1986.

Gleick, P.: The development and testing of a water balance model for climate impact assessment, modeling the Sacramento Basin, Water Resour. Res., 23(6), 1049-1061, 1987.

Hansen, J., Russel, G., Rind, D., Stone, P., Lacis,A., Lebedeff, S., Ruedy, R., and Travis, L.: Efficient three-dimensional global models for climate studies, Model I and II, Mont. Weather Rev., 111, 609-662, 1983.

Hanson, R. T., Newhouse, M. W., and Dettinger, M. D.: A methodology to assess relations between climatic variability and variations in hydrologic time series in the southwestern United States, J. Hydrol., 287, 252-269, 2004.

Hamed, K. H. and Ramachandra, R.: A modified Mann-Kendall trend test for autocorrelated data, J. Hydrol., 204(4), 182-196, 1998.

Helsel, D. R. and Hirsch, R. M.: Statistical methods in water resources, Elsevier Publishers, Amsterdam, Holland, 1992.

Hengeveld, H. G.: Projections for Canada's climate future, a discussion of recent simulations with the Canadian Global Climate Model, Environment Canada, Climate Change Digest, 00-01, 27 pp., 2000.

Hunter, T. S. and Croley, T. E.: Great Lakes monthly hydrologic Data, NOAA Data Report ERL GLERL, National Technical Information Service, Springfield, Virginia, 22161, 1993.

GLIN: The Great Lakes, Great Lakes Information Network, 2005, available at: http://www.great-lakes.net/lakes, last access: June 2006.

IPCC: Climate Change 1996: The Science of climate change, contribution of working group I to the second assessment report of 
the IPCC, Cambridge University Press, UK, 1996.

IPCC: The Climate Change 2001: Synthesis report, Cambridge University Press, Cambridge, United Kingdom, and New York, NY, USA, 398 pp., 2001.

IPCC: Fourth assessment report climate change 2007, Paris, http: //www.ipcc.ch/, 2007.

Kendall, M. G.: Rank Correlation Methods, 5th Edition, Edward Arnold, London, UK, 1960.

Lenters, J. D.: Shift In Great Lakes "Seasons" may reflect warming trend, International Association of Great Lakes Research, University Of Wisconsin-Madison, USA, 2000.

Lofgren, B. M., Quinn, F. H., Clites, A. H., Assel, R. A., Eberhardt, A. J., and Luukkonen, C. L.: Evaluation of potential impacts on Great Lakes water resources based on climate, 5 scenarios of two GCMs., J. Great Lakes Res., 28, 537-554, 2002.

Manabe, S. and Wetherald, B.: On the distribution of climate change resulting from an increase in $\mathrm{CO} 2$ content of the atmosphere, J. Atmos. Sci., 37, 99-118, 1980.

Montanari, A., Rosso, R., and Taqqu, M. S.: Some long-run properties of rainfall records in Italy, J. Geophys. Res., 101(D23), 431-438, 1996.

Mortsch, L., Hengeveld, H., Lister, M., Lofgren, B., Quinn, F., Slivitzky, M., and Wenger, L.: Climate change impacts on the Hydrology of the Great Lakes-St. Lawrence System, Canadian Water Resources Journal, 25(2), 153-179, 2000.

Mortsch, L., Alden, M., and Klaasen, J.: Development of climate change scenarios for impact and adapatation studies in the Great Lakes, St. Lawrence Basin, International Joint Communication Report Environment Canada, Downsview, Canada, 2005.

NOAA: Hydrology and Hydraulics Data, National Oceanic and Atmospheric Administration, Great Lakes Environmental Research Laboratory, Michigan, USA, available at: http://www.glerl.noaa. gov/data/pgs/hydrology.html, 2004.
NWP Association: Manual of STATLET, California, USA, http://

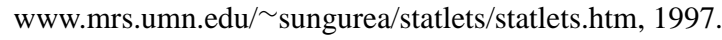

Quinn, F. H. and R. N. Kelley: Great Lakes Monthly Hydrologic Data, NOAA Data report, ERL, GLERL-26, National Technical Information Service, Springfield, USA, 22161, 1983.

Salas, J. D., Marco, J. B., and Harboe, R.: Stochastic Hydrology, Colorado State University, USA, 1993.

Statsoft Company: STTISTICA software, http://www.statsoft.com/ (last access: Sep 2007), 2006.

Sanderson, M.: Implications of climatic change for navigation and power generation in the Great Lakes, Climate Change Digest 8703, Environment Canada, 1987.

Sanderson, M. and Smith, J.: Climate change and water in the Grand, River Basin, Ontario, Proceedings of the 43rd Conference Canadian Water Resources Association, Penticton, Canada, 243-261, 1990.

Smith, J. V. and McBean, E.: The impact of climate change on surface water resources, in: The impact of climate change on water in the Grand River Basin, Ontario, edited by: Sanderson, M., Department of Geography Publication Series No. 40. Department of Geography, University of Waterloo, Waterloo, 25-52, 1993.

USEPA: The Great Lakes, United States Environmental Protection Agency, USA, http://www.epa.gov/glnpo/atlas/gl-fact1. html, 2005.

Wang, W., Van Gelder, P. H., Vrijling, H. J., and Chen, X.: Detecting long-memory, Monte Carlo simulations and application to daily streamflow processes, Hydrol. Earth Syst. Sci., 11, 851862, 2007, http://www.hydrol-earth-syst-sci.net/11/851/2007/. 